\title{
熱傷患者における血液凝固線溶系の変動とへパリン療法
}

$\begin{array}{cccc}\text { 小野 一郎* } & \text { 小椋 } & \text { 哲実* } & \text { 梅田 整* } \\ \text { 大浦 武彦* } & \text { 近藤 } & \text { 光** } & \end{array}$

\section{Alterations of coagulative and fibrinolytic activities in burn injuries and heparin therapy to burned patients}

\author{
Ichiro ONO*, Tetsumi OGURA*, Tadashi UMEDA*, \\ Takehiko OHURA* and Mitsuru KONDO**
}
Key words : burn injuries, disseminated intravascular coagul- ation syndrome (DIC), anticoagulant therapy, heparin, FOY

Burn injuries cause dynamic alterations of the coagulative and fibrinolytic activities of the blood. But there has been little research in this field.

In our research of burned patients who sustained burns over $30 \%$ of the total body surface area, platelet counts, PT, PTT, fibrinogen, ELT, fibrinolytic activities on various fibrin plates, FDP, $\alpha_{1}$-antitrypsin, $\alpha_{2}$-macroglobulin and antithrombin III were checked.

The results show that intravascular coagulation occurs soon after burn injury and it takes almost one month, including the passage through the hypercoagulative stage to normalize. So we devided the postburn period into 4 stages from the hematological standpoint.

Ist stage; within 48 hours. IInd stage; 3rd-7th day.

IIIrd stage; 8th-30th day. IVth stage; after 30th day.

We used heparin of $10,000-20,000 \mathrm{U}$ in dose on burned patients clinically to prevent the DIC in the Ist stage. From our experience, heparin therapy to burned patients is very effective and safe. But in severly burned patients, administration of FOY is recommended.

目的

重症熱傷患者において血液凝固線溶系が多大
の影響を受けるであろうととは想像に難くな く，日常経験する熱傷患者においてむいわゆ る DIC に至る症例は予想以上に多く認められ

* 北海道大学医学部形成外科〔干060 札幌市北区北14条西5丁目〕, Department of Plastic Surgery, Hokkaido University School of Medicine, Sapporo, Japan.

** 白石臨床検査研究所, Shiraishi Clinical Reserching Laboratory, Sapporo, Japan. 


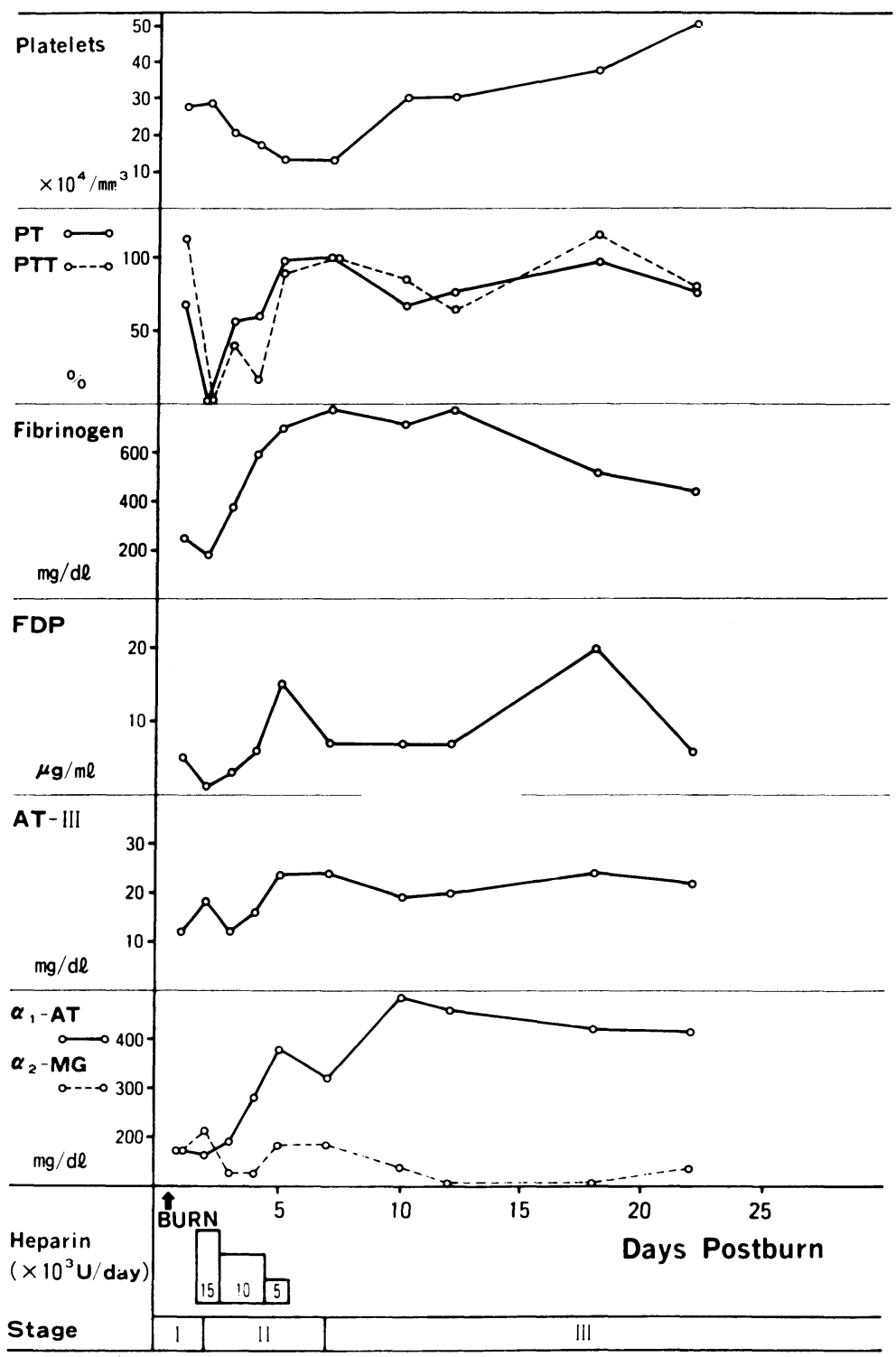

Fig. 1 Case 1; T. S., 30 y.o. 우, $80 \%$ burn.

る ${ }^{12)}$. しかしながら凝血学的立場から熱傷患 者に対する治療をみた場合，その対策は必ずし あ充分とはいえない状態であった。今回，われ われは熱傷患者に対する抗凝固療法の可能性に つき検討を加えたので報告する。

\section{I. 方 法}

われわれは最近経験した受傷面積 $30 \%$ 以上の 熱傷患者のうち, 比較的経過の順調であった 8 症例(受傷面積 $48.7 \pm 16.5 \%$ ) に対し, 血小板数, プロトロンビン時間 (PT), 部分トロンボプラ
スチン時間 (PTT), フィブリノーゲン, アン チトロンビン III， ユーグロブリン溶解時間 (E LT), 総プラスミノーゲン量, SK 活性化プラ スミン，フィブリン体分解産物 (FDP), $\alpha_{1}$-ア ンチトリプシン， $\alpha_{2}$-マクログロブリン等の諸 検査を施行し, 熱傷患者における正常の経過に つき検討した．また，熱傷患者に対する抗凝固 療法としてヘパリン，FOY を投与した症例に おいてあ血液凝固線溶系の変動につき詳細な検 査を行ない，その有効性につき検討を加えた。 


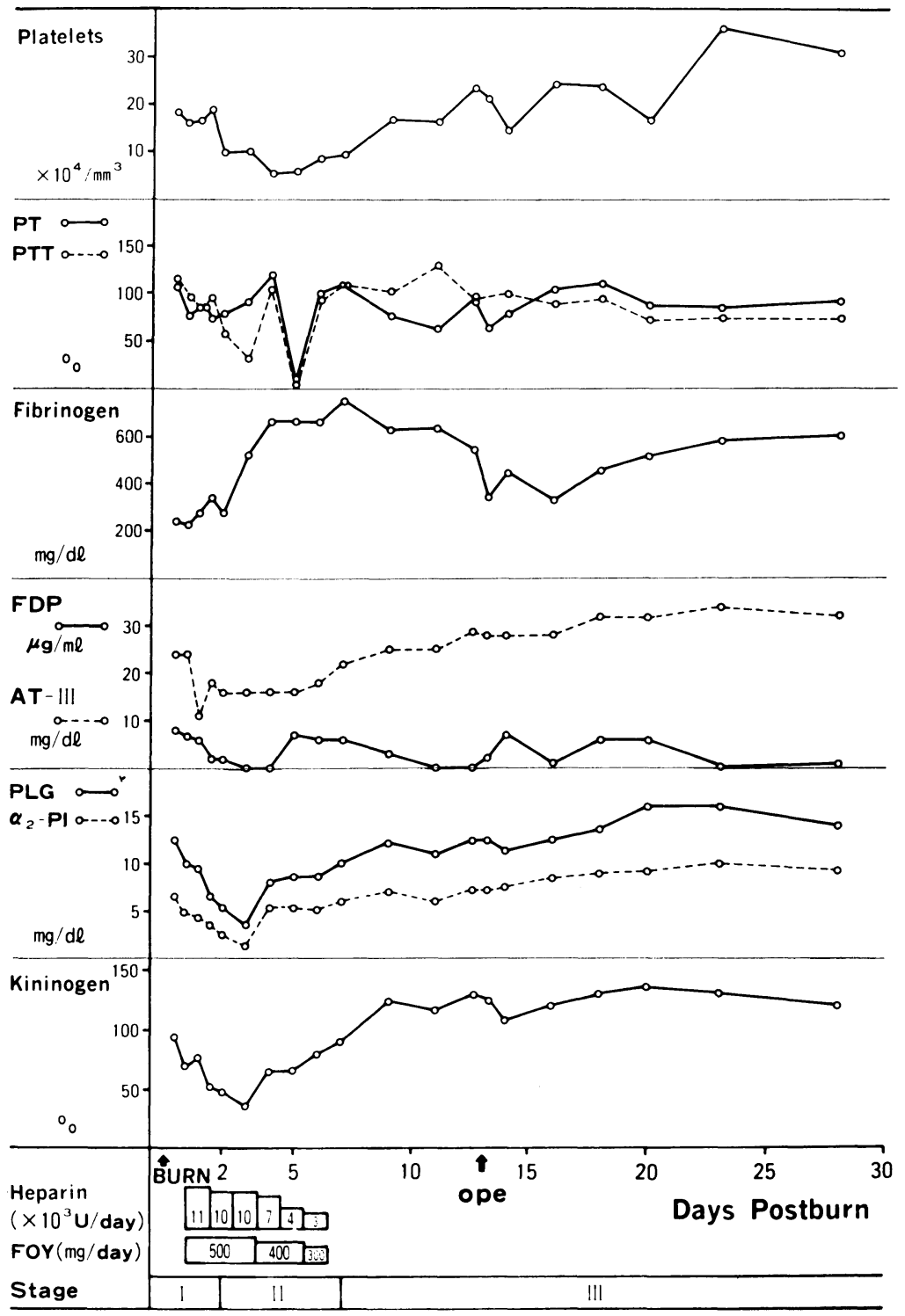

Fig. 2 Case 3; S. K., 25 y.o. 官, 65\% burn.

\section{II. 結 果}

1. 比較的経過の順調であった 8 例の重症熱 傷患者の諸検査の結果

血小板数は受傷直後から 5 日目頃までは減少 したが，その後は増加し，受傷後15日目頃最高 值となり，その後約 1 か月で正常化した. PT, PTT は受傷後にばらつきが大きく症例によっ ては延長した.またフィブリノーゲンは受傷直 後に軽度減少したが, 直ちに上昇し, 受傷後 10 日目に最高値となった後, 約 1 か月で正常化し
た. アンチトロンビンーIII あ受傷後低下する傾 向をみせたがやはり 1 か月程で正常化した。一 方，線溶系では ELT が受傷直後に短縮し，フ イブリン平板法により求めたプラスミノーゲン は受傷後 5 日目頃までは低下する傾向をみせ た。また $\alpha_{1}$-アンチトリプシンは受傷後10日目 頃を最高值として上昇したが， $\alpha_{2}$-マクログロ ブリンは変動しなかった．FDP は受傷直後に 上昇したが，その上昇の程度は重症な症例や治 療の開始が遅れた症例に，より顕著である傾向 が認められた。 
Table 1 Clinical course after burn injuries from hematological standpoint

\begin{tabular}{c|l|l}
\hline I st stage & within 48 hours & Intravascular coagulation-DIC \\
II nd stage & 3rd-7th day & Thrombocytepenia-bleeding \\
IIIrd stage & 8th-30th day & Hypercoagulation-DIC \\
IVth stage & after 30th day & Normalization \\
\hline
\end{tabular}

\section{2. 代表的 3 症例の結果}

\section{症例 1 ; T. S. 30歳, \& (80\%熱傷)}

この症例では入院時の検査ではとくに異常を 認めなかったが，重症熱傷患者である点を考慮 し，予防的ヘパリン療法を行った．入院直後に まず one shot で 5,000 単位静注し, その後 1 日当り 10,000 単位を 3 日間投与, その後 5,000 単位に減量し中止した. その結果, FDP の上 昇は軽度で，フィブリノーゲンは直ちに上昇す るなど重症例にもかかわらず経過はきわめて順 調であった（図1）.

症例 $2 ; \mathrm{H} . \mathrm{S} .34$ 歳, 今 (25\%熱傷)

この症例では受傷後 5 時間目迄は経過は順調 であったが，受傷後 8 時間目の検査で FDP が $70 \mu \mathrm{g} / \mathrm{m} l$ へと上昇したため，ヘパリン療法を 開始した。 その結果, 直ちに FDP は正常化 し，フィブリノーゲンあ上昇し始めた.

症例 $3 ； \mathrm{~S} . \mathrm{K} .25$ 歳, 令 (65\%熱傷)

この症例では入院時よりヘパリン療法を開始 し，さらに受傷後 10 時間より FOY を投与し た。 その投与は次第に漸減しながら 6 日間継続 し中止したが，その間 PT，PTT が延長する一 方, アンチトロンビン III, プラスミノーゲン等 は受傷後 3 日目まで減少した後直ちに上昇し始 めるというきわめて順調な経過をとり FDP あ 常に正常範囲にとどまった（図 2 ).

\section{III. 考 按}

以上述べたように, 経過の比較的順調であっ た熱傷患者においてあ受傷直後に DIC に準じ た変化をみせたのち，過凝固線溶抑制の時期を 経て正常化することが明らかとなったので，血 液学的立場から 4 期に分類した（表 1$)^{3}$.

この事実より，われわれは第 I 期に 1 日当 り，10,000〜20,000単位のヘパリンを投与した が，多くの症例で有効と考えられる結果であっ た.しかし，きわめて重症な熱傷患者に氺いて
は，ヘパリンの cofactor であるアンチトロンビ ン III が低值となり，ヘパリンの作用が発現しづ らくなる4) ばかりでなく，プラスミノーゲンの 消費む高度となるなど，ヘパリン単独療法の限 界あ明らかとなった。乙てれ対し，われわれは FOY をへパリンと併用して用いた症例を経験 し良好な結果を得た。今後はへパリンと FOY の併用療法, さらにはアンチトロンビン III 製剂 の投与を試みるなど5)，より効果的な抗凝固療 法につき検討する予定である.

\section{結 論}

熱傷患者においては第 I 期と第 III 期に DIC を発生する危険性が高く，とくに第 I 期では予 防的ヘパリン投与はきわめて有効でしかも安全 な治療法である。な技, 重症例ではアンチトロ ンビン III，プラスミノーゲンの減少が高度であ り, FOY の併用も有効と考えられる.

\section{文献}

1）小野一郎, 松本敏明, 吉田哲憲, 大浦武彦, 小室勝利：重症熱傷患者に発生した DIC の一 例. 熱傷, 2 (1)；87 93, 1976.

2) McManus, W. F., Eurenius, K., Pruitt, B. A. : Disseminated intravascular coagulation in burned patients. J. Trauma., 13 (5); 416 422, 1973.

3）小野一郎, 梅田 整, 吉田哲憲, 浜本淳二, 大浦武彦：熱傷患者における血液凝固線溶系 の変動. 熱傷, 4 (2)；136１44, 1979.

4) 小河原 緑, 平林直子, 関 俊子, 横内正利, 松田 保, 村上元孝：血中アンチトロンビン 低下時のへパリンの効果について。臨床血液, 20 (補冊 I )；269，1978.

5) 吉田信彦, 坂田洋一, 松田道生, 青木延雄: アンチトロンビン III 濃縮分画の使用経験. 臨 床血液, 20 (補冊 I )；269，1978. 